\title{
SYNTHESIS, CHARACTERIZATION AND ANTIVIRAL PROPERTIES OF Pd(II) COMPLEXES WITH PENCICLOVIR
}

\author{
A. Garoufis ${ }_{\text {A }}{ }^{\text {, K. Karidi }}{ }^{1}$, N. Hadjiliadis*1, S. Kasselouri ${ }^{2}$, J. Kobe ${ }^{3}$, \\ J. Balzarini ${ }^{4}$ and E. De Clercq ${ }^{4}$ \\ a Laboratory of Inorganic and General Chemistry, Department of Chemistry, \\ University of Ioannina, 45110 Ioannina, Greece \\ ${ }^{b}$ Department of Chemistry, Physics and Material Technology, \\ Technological Institution of Athens, 12210 Egaleo, Greece \\ ${ }^{c}$ National Institute of Chemistry, Hajdrihova 19, P.O.B. 3430, Ljubljana, Slovenia \\ d Katholieke Universiteit Leuven, Rega Institute for Medical Research, \\ Minderbroedersstraat 10, B-3000 Leuven, Belgium
}

\begin{abstract}
.
With the aim to improve and extend the antiviral activity of the antiherpic drug penciclovir, to a wider spectrum of viruses, we have synthesized and characterized new binary and ternary complexes of $\mathrm{Pd}(\mathrm{II})$ of formulae cis-(pen $)_{2} \mathrm{PdCl}_{2}$ and $c i s-\left[(\text { nucl })_{2} \mathrm{Pd}(\mathrm{pen})_{2}\right] \mathrm{Cl}_{2}$, where nucl $=$ guanosine, inosine, cytidine or penciclovir. The characterization was mainly based on IR and ${ }^{1} H$ NMR spectroscopy, and the results showed that in all prepared complexes, penciclovir coordinates to the metal through N7. The far-i.r. spectrum of the complex cis-(pen) ${ }_{2} \mathrm{PdCl}_{2}$ confirmed the cis- geometry around $\mathrm{Pd}(\mathrm{II})$. All the prepared complexes were markedly active against HSV-1 and HSV-2 strains, but not against thymidine kinase-deficient HSV-1 strains.
\end{abstract}

\section{Introduction.}

Acyclic nucleoside analogues are well known for their antiviral activity[1]. The antiherpic drug, acyclovir (ACV), was the first acyclic nucleoside analogue shown to be antivirally effective [2]. Various other guanosine analogues have been synthesized, among which penciclovir or 9(4-hydroxy-3(hydroxymethyl)but-1-yl)guanine (Fig. 1). Like acyclovir, penciclovir acts through a selective inhibition of viral DNA synthesis and replication [3]. For the acyclic nucleoside analogues to be antivirally active they must be enzymatically metabolized within the herpes virus-infected cells [4]. Thus the interactions of metal ions with acyclic nucleosides and their derivatives present a great interest, because the majority of enzymes, in virus-infected and uninfected cells, require metal ions for their activity [5]. Although several metal complexes of acyclovir have been synthesized, characterized and tested against a variety of viruses [6-10], to our knowledge, until today, there are not reports on the interaction of penciclovir with metal ions.

Herein we report on the synthesis, characterization and antiviral properties of some $\mathrm{Pd}(\mathrm{II})$ complexes with penciclovir.

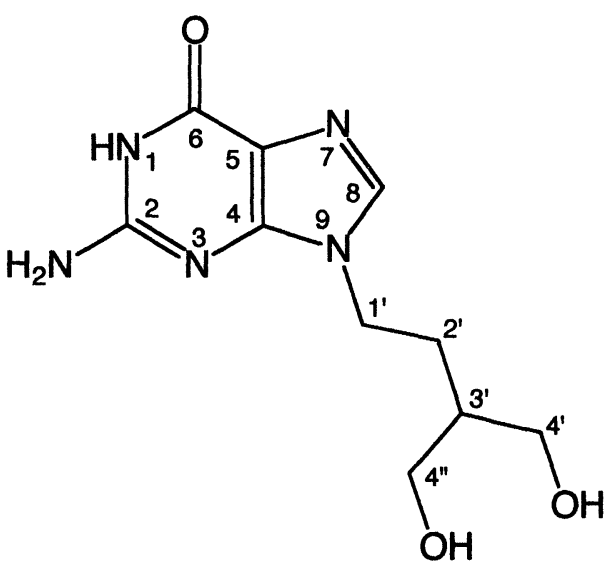

2. Materials and Methods

Figure 1 Molecular structure of Penciclovir

\subsection{Materials and physical measurements.}

The nucleosides guanosine, inosine, cytidine were purchased from Sigma and used without further purification. Palladium(II) chloride was obtained from Fluka A.G. Penciclovir [11], and the complexes (guo $)_{2} \mathrm{PdCl}_{2}$, (ino) ${ }_{2} \mathrm{PdCl}_{2}$ and (cyd) ${ }_{2} \mathrm{PdCl}_{2}$ were prepared according to the literature [12].

Mid- and far-i.r. spectra were recorded on a Perkin Elmer GX spectrophotometer in $\mathrm{KBr}$ and polyethylene pellets, respectively. ${ }^{1} \mathrm{H}$ NMR spectra were obtained on a Bruker AMX $400 \mathrm{MHz}$ and on Bruker AC $250 \mathrm{MHz}$ instrument. The sample temperature was set at $298^{\circ} \mathrm{K}$. 
cis- $\left[\mathbf{P d}(\mathrm{L})_{2}(\text { pen })_{2}\right] \mathbf{C l}_{2}$, cis-[bis(L)bis(penciclovir)palladium(II)]Dichloride $(\mathrm{L}=$ guanosine , inosine, cytidine). (I), (II), (IV)

General procedure: cis-[bis(L)dichloropalladium(II)] (L:guo, ino, cyd ) (0.5 mmol) was mixed with $(1 \mathrm{mmol})$ of penciclovir in the solid state, and $2 \mathrm{ml}$ of $\mathrm{D}_{2} \mathrm{O}$ was added. After stirring for about 20 min at $50{ }^{0} \mathrm{C}$ complete dissolution was achieved. The ${ }^{1} \mathrm{H}-\mathrm{NMR}$ spectrum of the mixture showed the end of the reaction. The complex was purified by chromatographic methods with Sephadex G-10. It was then precipitated with acetone, filtered off, washed with acetone ( $2 \times 5 \mathrm{ml})$ and ether ( $2 \times 5 \mathrm{ml})$ and finally dried at $110^{\circ} \mathrm{C}$ under vacuum over silica.

(I) $\left[\mathrm{Pd}(\text { ino })_{2}(\text { pen })_{2}\right] \mathrm{Cl}_{2}$. Anal. Calc. C, 40.3; H, 4.5; N, 21.1.Found: C, 39.9; H, 4.9: N, 20.1. (II) $\left.\left[\mathrm{Pd}(\text { guo })_{2} \text { (pen) }\right)_{2}\right] \mathrm{Cl}_{2}$. Anal. Calc. C, 39.3; H, 4.6; N, 22.9. Found: C, 38.6; H, 4.9; N, 22.5.

(IV) $\mathrm{Pd}(\text { cyd })_{2}$ (pen $)_{2} \mathrm{Cl}_{2}$. Anal. Calc. C, 39.9; $\mathrm{H}, 4.9 ; \mathrm{N}, 19.6$. Found: C, 39.2; H, 5.2: N, 19.3.

[Pd(pen) $)_{4} \mathbf{C l}_{2}$.] tetrakis(penciclovir)palladium(II) Dichloride. (III)

cis-[bis(penciclovir)dichloropalladium(II)] $(0.5 \mathrm{mmol})$ was mixed with $(1 \mathrm{mmol})$ of penciclovir in the solid state and $2 \mathrm{ml}$ of $\mathrm{D}_{2} \mathrm{O}$ was added. After stirring for about $20 \mathrm{~min}$ at $50{ }^{0} \mathrm{C}$, complete dissolution was achieved. The evolution of ${ }^{1} \mathrm{H}-\mathrm{NMR}$ spectra showed the end of the reaction. The complex was then precipitated with acetone, filtered, washed with acetone ( $2 \times 5 \mathrm{ml})$ and ether ( $2 \times 5$ $\mathrm{ml}$ ), and dried at $110^{\circ} \mathrm{C}$ under vacuum over silica. The complex was purified by chromatography on Sephadex G-10

(III) $\left[\mathrm{Pd}(\text { pen })_{4}\right] \mathrm{Cl}_{2}$. Anal. Calc. C, 42.3; H, 5.3; N, 24.7. Found: C, 41.2; H, 4.9; N, 23.8.

cis-[Pd(pen) ${ }_{2} \mathbf{C l}_{2}$ ]. cis-[bis(penciclovir) dichloropalladium(II)]. (V)

Palladium chloride $(0.5 \mathrm{mmol})$ was dissolved in $10 \mathrm{ml}$ of $0.5 \mathrm{~N} \mathrm{HCl}$ by heating to about $50{ }^{\circ} \mathrm{C}$. Penciclovir ( $1 \mathrm{mmol})$ was dissolved in $20 \mathrm{ml}$ of $0.5 \mathrm{~N} \mathrm{HCl}$. The two solutions were mixed at room temperature and stirred for $2 \mathrm{~h}$. The yellow precipitate that formed was filtered, washed with cold acetone and ether and dried at $110{ }^{\circ} \mathrm{C}$ under vacuum.

(V) $\mathrm{Pd}(\mathrm{pen})_{2} \mathrm{Cl}_{2}$. Anal. Calc. C, 36.4; $\mathrm{H}, 4.6 ; \mathrm{N}, 14.6$. Found: $\mathrm{C}, 36.2 ; \mathrm{H}, 4.4 ; \mathrm{N}, 14.8$.

\section{Results and discussion.}

\subsection{Synthesis.}

The reaction of $\mathrm{H}_{2} \mathrm{PdCl}_{4}$ with penciclovir at molar ratio $1: 2$, in strong acidic solutions $(0.5 \mathrm{~N}$ $\mathrm{HCl}$ ), produces the cis-(pen $)_{2} \mathrm{PdCl}_{2}$, because the trans- influence of pen is comparable to that of pyridine [13] (eq 1). The cis- configuration around the metal was confirmed by a Kurnakoff test [14]. A mixture of the above complex and excess of thiourea, were mixed in the solid state and dissolved in $\mathrm{D}_{2} \mathrm{O}$. The ${ }^{1} \mathrm{H}$ NMR spectrum of the mixture showed the presence of free penciclovir.

$\mathrm{H}_{2} \mathrm{PdCl}_{4}+2$ pen $\longrightarrow$ cis-(pen) $)_{2} \mathrm{PdCl}_{2}+2 \mathrm{HCl}$

The reaction of cis-(pen) ${ }_{2} \mathrm{PdCl}_{2}$ with penciclovir in a molar ratio of $1: 2$ in aqueous media, formed the soluble complex [tetrakis(penciclovir)palladium(II)] Dichloride, $\left[\mathrm{Pd}(\mathrm{pen})_{4}\right] \mathrm{Cl}_{2}$, according to eq. 2

$$
\underline{\text { cis- }} \text { (pen })_{2} \mathrm{PdCl}_{2}+2 \text { pen } \longrightarrow\left[(\text { pen })_{4} \mathrm{Pd}\right] C l_{2} \text { (2) }
$$

Mixed nucleoside palladium(II) complexes were prepared by a similar procedure upon the reaction of cis-(guo $)_{2} \mathrm{PdCl}_{2}$, cis-(ino $)_{2} \mathrm{PdCl}_{2}$ and $\underline{\text { cis- }}-(\mathrm{cyt}){ }_{2} \mathrm{PdCl}_{2}$ with free penciclovir.

\subsection{Spectroscopic characterization of the complexes.}

\subsubsection{Infrared spectroscopy.}

The i.r. spectra of the complexes showed a strong band invariably at 1697 to $1726 \mathrm{~cm}^{-1}$ assigned to free $(\mathrm{C}=\mathrm{O})$ of the $6^{\text {th }}$ position of the purine ring or the $3^{\text {th }}$ position of the pyrimidine ring, in the case of cyd containing complexes, excluding the formation of a $\mathrm{Pd}-\mathrm{O}$ bond through the carbonyl group or the coordination through the neighboring N1. A similar behavior was observed in the infrared spectra of trans- and cis-(nucl $)_{2} \mathrm{PdCl}_{2}$ or mixed trans- or cis-[(nucl) $\left.)_{2} \mathrm{Pd}(\text { nucl' })_{2}\right] \mathrm{Cl}_{2}$, were nucl or nucl $=$ guanosine, inosine or cytidine $[12,13]$. In addition all spectra of the prepared complexes, exhibited $\bar{a}$ broad band at about 425 to $430 \mathrm{~cm}^{-1}$, attributed to $\mathrm{Pd}-\mathrm{N}$ stretching vibration, suggesting coordination through N7. The far-i.r. spectrum of the binary complex cis-(pen) ${ }_{2} \mathrm{PdCl}_{2}$ exhibited two strong to medium intensity bands at 325 and $329 \mathrm{~cm}^{-1}$ assigned to $\mathrm{Pd}-\mathrm{Cl}$ stretching vibration, confirming the cisconfiguration of the chlorine atoms [16].

The characteristic i.r. bands for the complexes and the

TABLE I. Characteristic i.r. ${ }^{a}$ and far-i.r. ${ }^{a}$ bands $\left(\mathrm{cm}^{-1}\right)$ for the complexes and the free ligand.

\begin{tabular}{llllll}
\hline Compounds & $v_{\mathrm{a}}(\mathrm{C}=\mathrm{O})$ & $\delta\left(\mathrm{NH}_{2}\right)$ & $v(\mathrm{C}=\mathrm{C}, \mathrm{C}=\mathrm{N})^{\mathrm{b}}$ & $v(\mathrm{Pd}-\mathrm{N})$ & $v(\mathrm{Pd}-\mathrm{Cl})$ \\
\hline Penciclovir & $1692 \mathrm{~s}$ & $1645 \mathrm{~m}$ & $1604 \mathrm{~s} 1546 \mathrm{~m}$ & & \\
cis-(pen $)_{2} \mathrm{PdCl}_{2}$ & $1726 \mathrm{~s}$ & $1642 \mathrm{~s}$ & $1625 \mathrm{~m} \mathrm{1550 \textrm {b }}$ & $430 \mathrm{~m} 419 \mathrm{w}$ & $325 \mathrm{~s} 339 \mathrm{~m}$ \\
\hline$\left.[\text { (pen })_{4} \mathrm{Pd}\right] \mathrm{Cl}_{2}$ & $1712 \mathrm{~s}$ & $1640 \mathrm{~s}$ & $1620-1530 \mathrm{~b}$ & $425 \mathrm{w}$ & \\
cis-[(guo $\left.)_{2} \mathrm{Pd}(\text { pen })_{2}\right] \mathrm{Cl}_{2}$ & $1697 \mathrm{~s}$ & $1637 \mathrm{~s}$ & $1598 \mathrm{~s}$ & $430 \mathrm{w}$ & \\
cis-[(ino $\left.)_{2} \mathrm{Pd}(\text { pen })_{2}\right] \mathrm{Cl}_{2}$ & $1701 \mathrm{~s}$ & $1635 \mathrm{~s}$ & $1592 \mathrm{~b}$ & $428 \mathrm{w}$ & \\
\hline cis-[(cyd $\left.)_{2} \mathrm{Pd}(\text { pen })_{2}\right] \mathrm{Cl}_{2}$ & $1720 \mathrm{~s}$ & $1678 \mathrm{~s} 1664 \mathrm{~s}$ & $1620 \mathrm{w} 1592 \mathrm{~b}$ & $430 \mathrm{~m}$ & \\
\hline
\end{tabular}

${ }^{a}$ Fourier-transform spectra. ${ }^{b}$ skeletal vibrations. Abbreviations: $b=$ broad, $m=$ medium, $s=$ strong, $w$ = weak. 


\subsection{2 ${ }^{1}$ H NMR spectroscopy.}

The $\mathrm{H} 8$ resonance of penciclovir, in the ${ }^{1} \mathrm{H}$ NMR spectra of all five prepared complexes showed a downfield shift by 0.38 to $0.46 \mathrm{ppm}$, compared to the free ligand in $\mathrm{D}_{2} \mathrm{O}$, indicating a covalent interaction of the $\mathrm{Pd}(\mathrm{II})$ ion with the neighboring to H8, nitrogen atom of the purine ring (N7). Similar strong downfield shifts of the guanosine's $\mathrm{H} 8$ proton, were observed in the binary or ternary complexes of the ligand with $\mathrm{Pd}(\mathrm{II})[12,13]$. It is noticeable that in the spectrum of cis-(pen) $)_{2} \mathrm{PdCl}_{2}$ ( in $\mathrm{DCl} 1 \mathrm{~N}$ ) the $\mathrm{H} 8$ proton resonance shifts upfield, compared with the protonated at $\mathrm{N} 7$ form of penciclovir, pen (in $\mathrm{DCl} 1 \mathrm{~N}$ ), by about $0.47 \mathrm{ppm}$, indicating that the $\mathrm{H}^{+}$causes higher electron deshielding in the magnetic environment of the H8 nucleus than the palladium ion.

TABLE II gives the ${ }^{1} \mathrm{H}$ NMR chemical shifts of the prepared complexes.

TABLE II. $400 \mathrm{MHz}{ }^{1} \mathrm{H}$ NMR chemical shifts (ppm) a,b of the prepared complexes and the free ligand.

PENCICLOVIR PROTONS

NUCLEOSIDE PROTONS

\begin{tabular}{|c|c|c|c|c|c|c|c|c|c|}
\hline Compounds & solvent & H8 & H1' & H2' & H3' & H4' \& H4" & H8 & $\mathrm{H} 2$ & H5 \\
\hline \multirow[t]{2}{*}{ Penciclovir } & $\mathrm{D}_{2} \mathrm{O}$ & 7.90 & 3.99 & 1.70 & 1.45 & 3.40 & & & \\
\hline & DCl $1 \mathrm{~N}$ & 8.69 & 4.06 & 1.67 & 1.46 & 3.49 & & & \\
\hline cis-(pen) $)_{2} \mathrm{PdCl}_{2}$ & DCl $1 \mathrm{~N}$ & 8.22 & 4.02 & 1.67 & 1.45 & 3.52 & & & \\
\hline${ }^{\mathrm{c}}\left[(\text { pen })_{4} \mathrm{Pd}\right] \mathrm{Cl}_{2}$ & $\mathrm{D}_{2} \mathrm{O}$ & 8.36 & 4.01 & 1.69 & 1.45 & 3.42 & & & \\
\hline${ }^{\circ}$ cis- $\left[(\text { guo })_{2} \mathrm{Pd}(\mathrm{pen})_{2}\right] \mathrm{Cl}_{2}$ & $\mathrm{D}_{2} \mathrm{O}$ & 8.39 & 4.09 & 1.70 & 1.39 & 3.45 & 8.94 & & \\
\hline${ }^{\circ}$ cis- $\left.[\text { (ino })_{2} \mathrm{Pd}(\text { pen })_{2}\right] \mathrm{Cl}_{2}$ & $\mathrm{D}_{2} \mathrm{O}$ & 8.28 & 4.06 & 1.72 & 1.45 & n.a. & 8.98 & 8.20 & \\
\hline${ }^{\mathrm{c}}$ cis- $\left[(\mathrm{cyd})_{2} \mathrm{Pd}(\text { pen })_{2}\right] \mathrm{Cl}_{2}$ & $\mathrm{D}_{2} \mathrm{O}$ & 8.23 & 4.05 & 1.71 & 1.36 & n.a. & & & 8.18 \\
\hline
\end{tabular}

${ }^{a}$ Spectra recorded at ambient temperature. ${ }^{b}$ The values are referenced to the HDO peak which has been set at 4.82 ppm.

${ }^{\mathrm{c}} 250 \mathrm{MHz}$ spectra. $\mathrm{n} \cdot \mathrm{a}=$ not assigned.

\subsection{Antiviral properties.}

All prepared penciclovir complexes were markedly active against HSV-1 and HSV-2 strains but not against thymidine kinase-deficient (TK') HSV in $\mathrm{E}_{6} \mathrm{SM}$ cell cultures (TABLE III). The compounds were also inactive against a variety of other viruses including vesicular stomatitis virus, Coxsackie virus B4 and respiratory syncytial virus in HeLa cell cultures (TABLE IV) and against parainfluenza-3 virus, reovirus-1, Sindbis virus, Coxsackie virus B4 and Punta Toro virus in Vero cell cultures (TABLE V). They were also not active against human immunodeficiency virus type $1\left(\mathrm{III}_{\mathrm{B}}\right)$ and type 2 (ROD) in CEM and MT-4 cell cultures (data not shown). None of the compounds proved markedly cytostatic against murine leukemia L1210, murine mammary carcinoma FM3A and human lymphocyte Molt4 and CEM cells (50\% inhibitory concentration $>100 \mu \mathrm{M}$ ) (except for compound II that inhibited Molt4 and CEM cell proliferation at 30-34 $\mu M)$ (TABLE VI). Clearly, the compounds I-V displayed a similar antiviral spectrum as the parent compound penciclovir. However, they were not superior to penciclovir in inhibiting herpes virus-induced cytopathicity in cell culture. Also, the test compounds lost marked activity against a TK-deficient herpes simplex virus as also penciclovir did. In general, the most active compound was III that contained four penciclovir molecules for each Pd atom in the entire molecule.

In conclusion, the Pd containing penciclovir derivatives had a comparable antiviral spectrum as penciclovir (i.e. herpes simplex virus type 1 and 2), but were not superior to the parent compound.

\subsection{Broad-spectrum antiviral activity assays}

For herpes simplex viruses (HSV), vaccinia virus (VV), Coxsackie virus type B4, vesicular stomatitis virus (VSV), parainfluenza virus type 3, respiratory syncytial virus (RSV), Sindbis virus, Punta Toro virus and reovirus type 1 , the origin of the virus stocks $[17]$ and the assay procedures $[18,19]$ have been described previously. HSV assays were carried out against HSV-1 TK ${ }^{+}$(KOS, F and McIntyre) and HSV-2 (G and Lyons) and against HSV-1 TK (B2006) in embryonic skin muscle ( $\mathrm{E}_{6} \mathrm{SM}$ ) and human embryonic lung (HEL) cell cultures. Ribavirin, ganciclovir, penciclovir, (S)-DHPA, BVDU and ACV were used as reference compounds.

The cytostatic activity measurements were basically described [20]. Briefly, tumor cells were seeded at $\sim 250,000-300,000 \mathrm{cells} / \mathrm{ml}$ in $200 \mu \mathrm{l}$-wells of 96-wells microtiter plates and incubated for 2 days (L1210, FM3A) or 3 days (Molt4/C8, CEM) at $37^{\circ} \mathrm{C}$ in a humidified $\mathrm{CO}_{2}$-controlled atmosphere. At the end of the incubation period, cells were counted with a Coulter counter and the $\mathrm{IC}_{50}(50 \%$ inhibitory concentration) determined as the compound concentration required to inhibit tumor cell proliferation by $50 \%$. 


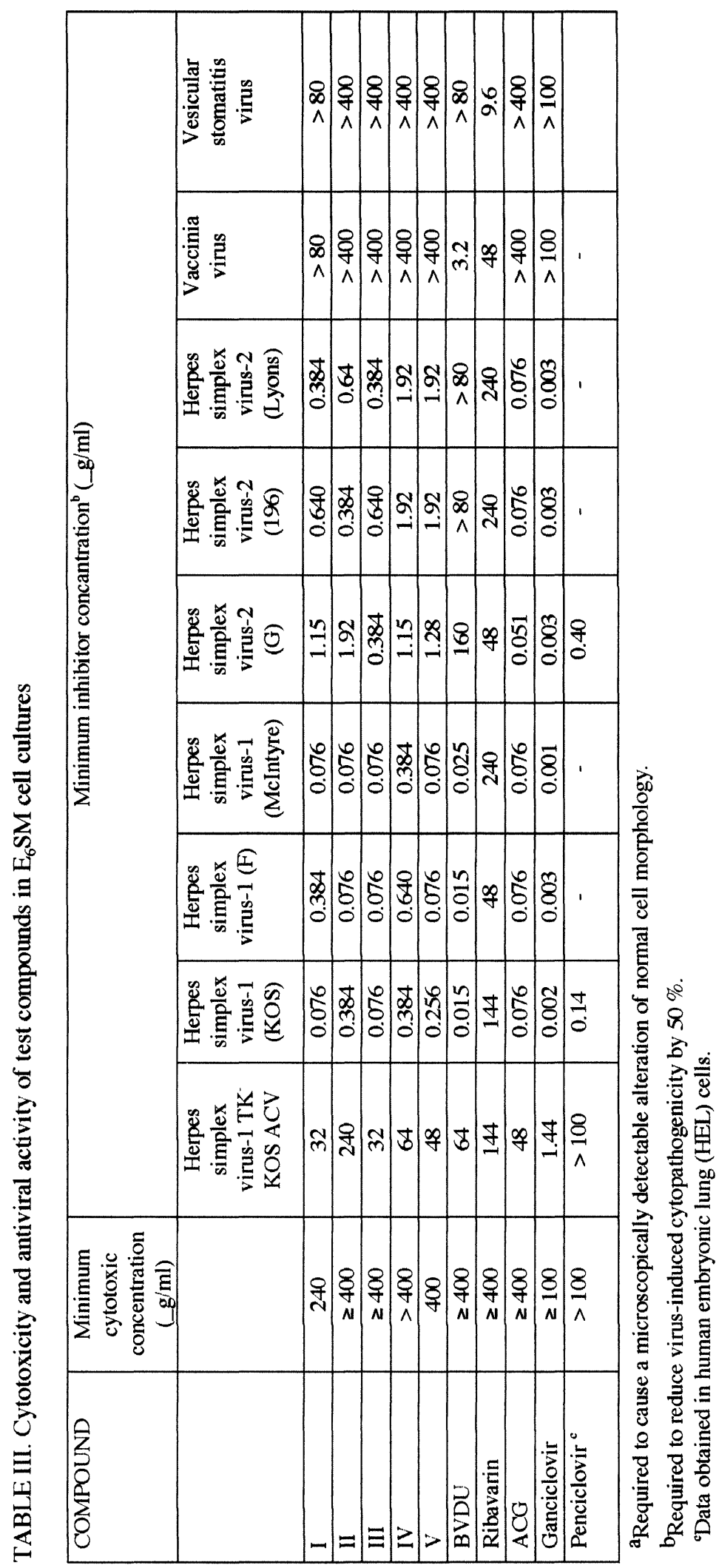




\subsection{Broad-spectrum antiviral activity assays}

For herpes simplex viruses (HSV), vaccinia virus (VV), Coxsackie virus type B4, vesicular stomatitis virus (VSV), parainfluenza virus type 3, respiratory syncytial virus (RSV), Sindbis virus, Punta Toro virus and reovirus type 1, the origin of the virus stocks [17] and the assay procedures $[18,19]$ have been described previously. HSV assays were carried out against HSV-1 TK ${ }^{+}$(KOS, F and McIntyre) and HSV-2 (G and Lyons) and against HSV-1 TK (B2006) in embryonic skin muscle $\left(\mathrm{E}_{6} \mathrm{SM}\right)$ and human embryonic lung (HEL) cell cultures. Ribavirin, ganciclovir, penciclovir, (S)-DHPA, BVDU and ACV were used as reference compounds.

The cytostatic activity measurements were basically described [20]. Briefly, tumor cells were seeded at $\sim 250,000-300,000 \mathrm{cells} / \mathrm{ml}$ in $200 \mu \mathrm{l}$-wells of 96-wells microtiter plates and incubated for 2 days (L1210, FM3A) or 3 days (Molt4/C8, CEM) at $37^{\circ} \mathrm{C}$ in a humidified $\mathrm{CO}_{2}$-controlled atmosphere. At the end of the incubation period, cells were counted with a Coulter counter and the $\mathrm{IC}_{50}(50 \%$ inhibitory concentration) determined as the compound concentration required to inhibit tumor cell proliferation by $50 \%$.

TABLE IV. Cytotoxicity and antiviral activity of test compounds in HeLa cell cultures

\begin{tabular}{|c|c|c|c|c|}
\hline \multirow[t]{2}{*}{ Compound } & \multirow{2}{*}{$\begin{array}{l}\text { Minimum } \\
\text { cytōoxic } \\
\text { concentration }^{\mathrm{a}} \\
(\mu \mathrm{g} / \mathrm{ml})\end{array}$} & \multicolumn{3}{|c|}{ Minimum inhibitory concentration ${ }^{b}(\mu \mathrm{g} / \mathrm{ml})$} \\
\hline & & $\begin{array}{l}\text { Vesicular } \\
\text { stomatitis } \\
\text { virus }\end{array}$ & $\begin{array}{l}\text { Coxsackie } \\
\text { virus B4 } \\
\text { virus }\end{array}$ & $\begin{array}{l}\text { Respiratory } \\
\text { syncytial }\end{array}$ \\
\hline I & $>400$ & $>400$ & 240 & $>400$ \\
\hline II & $>400$ & $>400$ & $>400$ & $>400$ \\
\hline III & $>400$ & $>400$ & $>400$ & $>400$ \\
\hline IV & $>400$ & $>400$ & $>400$ & $>400$ \\
\hline V & $>400$ & 240 & 240 & $>400$ \\
\hline BVDU & $>400$ & $>400$ & $>400$ & $>400$ \\
\hline (ㅇ)-DHPA & $>400$ & 240 & $>400$ & $>400$ \\
\hline Ribavirin & $>400$ & 48 & 48 & 0.64 \\
\hline
\end{tabular}

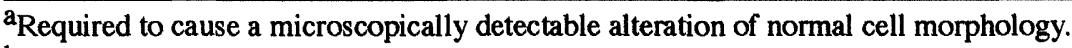

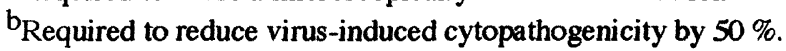


N. Hadjiliadis et al.

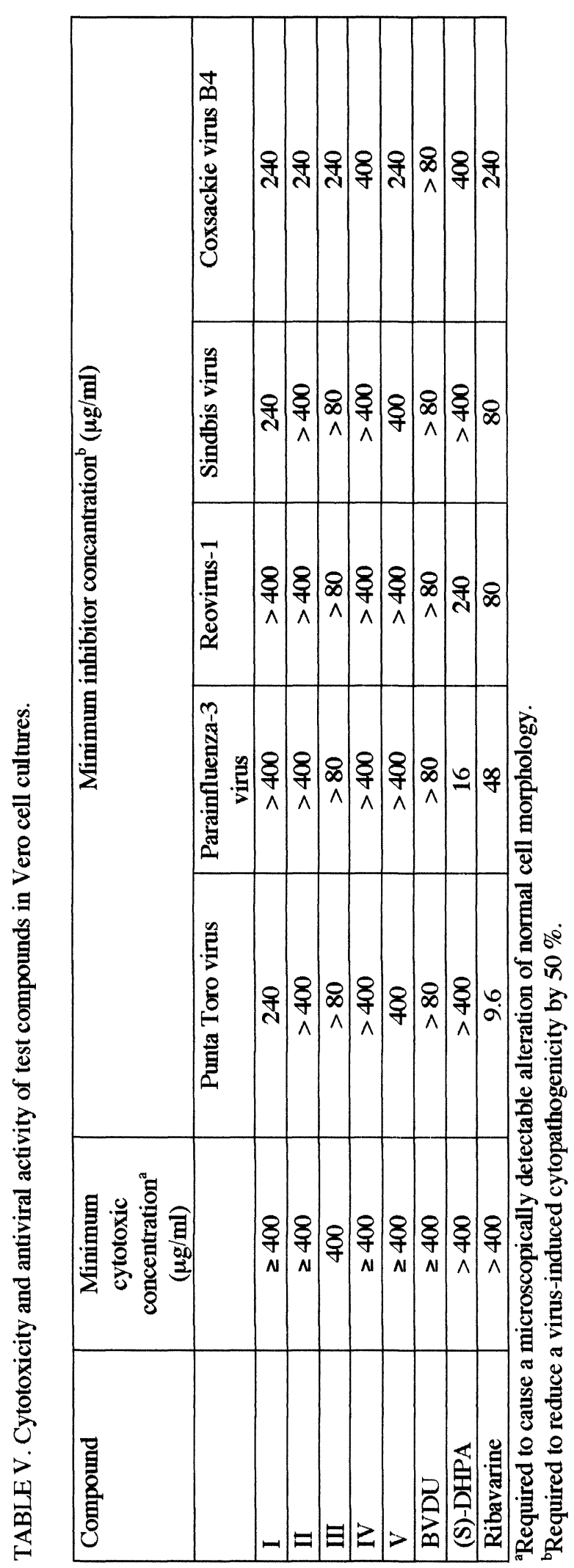

Synthesis, Characterization and Antiviral Properties of Pd(II) Complexes with Penciclovir 
TABLE VI. Inhibitory effects of test compounds on the proliferation of murine leukemia cells (L1210/0), murine mammary carcinoma cells (FM3A) and human T-lymphocyte cells (Molt4/C8, CEM/0)

\begin{tabular}{|l|c|c|c|c|}
\hline Compound & \multicolumn{3}{|c|}{$\mathrm{IC}_{50}(\mu \mathrm{M})$} \\
\hline I & L1210 & FM3A & Molt4/C8 & CEM \\
\hline II & $196 \pm 76$ & $>250$ & $\geq 250$ & $199 \pm 72$ \\
\hline III & $115 \pm 50$ & $170 \pm 3$ & $34 \pm 2$ & $30 \pm 5$ \\
\hline IV & $175 \pm 105$ & $>250$ & $198 \pm 5$ & $207 \pm 37$ \\
\hline V & $>250$ & $>250$ & $>250$ & $>250$ \\
\hline
\end{tabular}

${ }^{\mathrm{a}} 50 \%$ inhibitory concentration.

\section{References.}

1. (a) G.B. Elion, P.A. Furman, J.A. Fyfe, P. de Miranda, L. Beauchamp, H.J. Schaeffer Proc. Natl. Acad. Sc. USA. (1977), 74, 5717. (b) H.J. Schaeffer, L. Beauchamp, P. de Miranda, G.B. Elion, D.J. Bauer, P. Collins Nature (London). (1978), $272,583$.

2. J. A. Fyfe, P. M. Keller, P. A. Furman, R. L. Miller, G. B. Elion, J. Biol. Chem., (1978) 2538721

3. Shaw T., Amor P., Civitico G., Boyd M. and Locarnini S. Antimicrob. Agents Chemother, (1994) 38719. G. B. Elion, J. Antimicrob. Chemother., (1983) 12 Suppl. B 9

4. G. B. Elion, J. Antimicrob. Chemother., (1983) 12 Suppl. B 9

5. Williams R. J. P. Pure Appl. Chem. (1983) 55_35.

6. (a) L. Cavallo, R. Cini, J. Kobe, L.G. Marzilli, G Natile, J. Chem. Soc. Dalton Trans. (1991) 1867. (b) A. Garcia-Raso, J. J. Fiol, F. Badenas, R. Cons, A. Terron, M. Quiros, J. Chem. Soc. Dalton Trans. (1999) 167.

7. I. Turel, I. Leban, K. Gruber, J. Inorg. Biochem. (1996) 6341.

8. I. Turel, N. Bukovec, M. Goodgame, D. J. Williams, Polyhedron (1997) 161701.

9. (a) S. Grabner, J. Plavec, N. Bukovec, D. Di Leo, R. Cini, G. Natile, J. Chem. Soc. Dalton Trans. (1998) 1447.

10. Z. Balcarova, J. Kasparkova, A. Zakovska, O. Novakova, M.F. Sivo, G. Natile, V. Brabec, Mol. Pharm. (1998) 53846

11. J. Kobe, PATENT, International Application Number PCT/SI99/00021

12. G. Pneumatikakis, N. Hadjiliadis T. Theophanides, Inorg. Chem. 197817915

13. N. Hadjiliadis, T. Theophanides, Inorg. Chim. Acta (1976) 1677

14. N. S. Kurnakoff, J. Prakt. Chem. 189450483.

15. N. Hadjiliadis, G. Pneumatikakis, J. Chem. Soc. Dalton Trans. 19781691

16. K. Nakamoto, "Infrared and Raman Spectra of Inorganic and Coordination Compounds", $5^{\text {th }}$ Ed. J. Wiley and Sons, Inc.1997, Part B, p.185.

17. M. Witvrouw, D. Daelemans, C. Pannecouque, J. Neyts, G. Andrei, R. Snoeck, A.-M. Vandamme, J. Balzarini, J. Desmyter, M. Baba, E. De Clercq, Antiviral Chem. Chemother. (1998) 9 403-411.

18. E. De Clercq, M. Luczak, J.C. Reepmeyer, K.L. Kirk, L.A. Cohen, Life Sci. (1975) 17 187-194.

19. E. De Clercq, J. Descamps, G. Verhelst, R.T. Walker, A.S. Jones, P.F. Torrence, D. Shugar, J. Infect. Dis. (1980) 141 563-574.

J. Balzarini, E. De Clercq, M.P. Mertes, D. Shugar, P.F. Torrence, Biochem. Pharmacol. (1982) 31, $3673-3682$. 